\title{
遠心型血液ポンプのインペラに作用するふれまわり流体力に関する実験的研究
}

Experimental Study on the Whirling Fluid Force on the Impeller of a Centrifugal Pump for

\section{Ventricular Support}

$\begin{array}{llll}\text { 正 } & \text { 築谷朋典 (国循研) } & \text { 正 堀口祐憲 (阪大基礎工) } \\ \text { 正 辻本 良信 (阪大基礎工) } & \text { 非 妙中義之 (国循研) }\end{array}$

\begin{abstract}
Tomonori TSUKIYA, National Cardiovascular Center, Fujishirodai 5-7-1, Suita 565-8565 Hironori HORIGUCHI, Yoshinobu TSUJIMOTO, Osaka University Yoshiyuki TAENAKA, National Cardiovascular Center
\end{abstract}

Key Words: Centrifugal Pump, Ventricular Assist Device, Whirling, Unsteady Flow

1 はじめに 重症心不全患者の心臟ポンプ機能を補助・代替 する補助人工心臓システムとして，小型化が容易なターボ型ポ ンプ (軸流・遠心) の開発が進められており，すでに臨床応用 も開始されている。最大の課題は軸シール部を持たず，かつイ ンペラが機械的に接触せずに回転する機構の実現であり，非接 触の軸受（動圧・磁気浮上）が用いられる傾向にある。軸受の 剛性が低いこれらの方式について，インペラのふれまわり運動 が不安定にならないための設計法の確立を目的として, 永久磁 石カップリングを持つ遠心ポンプのインペラのふれまわり運動 を調べてきた。本研究では，流量が一定の場合に観察されたふ れまわり運動の主因を明らかにすることを目的として，インペ ラのバランスホールを閉塞したモデルについてインペラの変位 計測を行った。次いで，インペラに作用する流体力の軽減のた めに，理想的な形状と考えられる2つの対称な出口をもつケー シングを製作し，ふれまわりの測定を行った．また，流量が急 激に低下する場合の過渡的な挙動を明らかにするべく流路を急 閉塞・急開放させた場合についても検討した。

2 研究方法 計測対象として, 当研究施設にて開発した遠心 血液ポンプを使用した．インペラは翼内径 $26 \mathrm{~mm}$, 外径 $40 \mathrm{~mm}$ で 6 枚の円弧翼が永久磁石を内部に持つブシュと結合した構造 をとっている。 この永久磁石はケーシング壁を隔てて半径方向 に対向するリング状の駆動用永久磁石（モー夕軸に直結）とと もに磁気カップリングを形成し，インペラを駆動する。ブシュと ケーシング壁はそれぞれ円筒形であり，同心の位㯰にある場合 には $0.5 \mathrm{~mm}$ の隙間を有する.ブシュ中心には直径 $5 \mathrm{~mm}$ の孔が 貫通しており，インペラにより発生した圧力差を利用してケー シング底面部に流れを誘起する構造になっている，本研究では この貫通孔がふれまわり運動に与える影響を明らかにする目的 で，貫通孔を閉塞したインペラを作成した。 また，インペラに 作用する半径方向流体力を最小にし，インペラの振動を最小限 に抑える方策を得るために, 軸対称に二つの出口を持つケーシ ングを作成した。さらに，左心補助人工心臓には生体心の拍動 の影響や，回転数が高すぎる場合には心室壁が脱血管を閉塞し 流量が急激に低下寸る現象が発生する。そのような非定常性が 強い流量変動の場合のインペラ挙動に関しても計測を行った.

\section{3 実験結果}

3.1 貫通孔を閉塞したインペラ 流量の増加とともに平均中 心位置がケーシング出口方向に移動することは貫通孔をもつモ デルと同様であるが，ふれまわり運動とインペラ回転の角速度
比 $\Omega / \omega$ に関しては流量に依存せずほぼ 0.5 の値であった。貫通 孔が存在している場合には， $\Omega / \omega$ の値は締め切り時で約 0.7 の 值をとり, 流量が増加するに従い低下して 0.5 に達する.

3.2 対称に出口を 2つ持つケーシング 出口を対称に 2 箇所 設けたモデルでは，インペラはほぼ流量に拠らずケーシング中 心に位置していた。このことより実機のケーシングにおいて観 察された流量とともに平均位置が移動していく現象の原因は非 対称の円形ケーシングによる半径方向スラストによるものであ ることが示された。一方で, $\Omega / \omega$ の值に関しては約 0.6 から流 量の増加とともに 0.5 まで低下して掞り, 出口が一つの実機と 同様の傾向を示した。このことより，インペラのふれまわり運 動はケーシングの非対称性によるものではないことが示された。 3.3 流量の急閉塞時の挙動 Fig.1 に流量係数 $\phi$ が 0.052 の 状態から急閉塞した場合の流量波形とインペラ中心の軌跡を, $p h i=0.052$ と $\phi=0$ のとき定常状態の結果に重ねて示してい る。流量が急激に減少した場合にも，その中心の軌跡は定常状 態で計測した範囲内に収まっており, 急激な流量変動に伴う非 定常性は見られなかった。

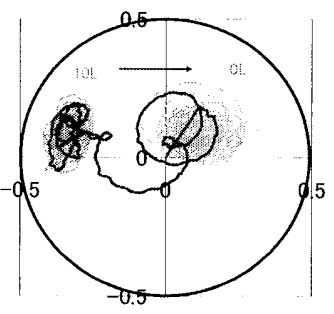

Fig.1 Locus of the impeller center in a sudden shutoff of the flow circuit.

4 まとめ 永久磁石カップリング駆動方式の遠心ポンプに関 して,インペラの変位計測を行いふれまわり運動に関する検討 を行った．本研究では，貫通孔を閉塞することによりふれまわ り運動の角速度と流量の関係がほぼ一定值 $(\Omega / \omega=0.5)$ になつ たことから，動圧軸受として作用しているブシュとケーシング の隙間に流入する漏孔流れのもつ角運動量の影響が強いこと, 対称ケーシングを用いることで半径方向スラストが顕著に低減 可能であること, 左心補助人工心臓で発生する程度の流量変動 ではインペラの挙動に顕著な非定常性は見られないことが示さ れた。 